\title{
Impact of Organizational Justice on Engineering Workers Job Satisfaction (a Research on 100 Engineering Workers Are Working in Department of Electrical at Al-Arabia Sugar Mill, Noon Sugar Mill and Shakarganj Sugar Mill Manufacturing Plants in Sugar Industry of Pakistan)
}

\author{
Kamran Nawaz ${ }^{1}$, Mudassar Usman², Muhammad Nadeem ${ }^{3}$, Fatima Nisar ${ }^{2}$, Kashif Saleem ${ }^{1}$ \\ ${ }^{1}$ International Islamic University, Islamabad, Pakistan \\ ${ }^{2}$ Bahria University, Islamabad, Pakistan \\ ${ }^{3}$ University of Sargodha, Sargodha, Pakistan \\ Email: *Kamran.nawaz143@gmail.com, Mudassar.usman114@gmail.com, M.nadeem@uos.edu.pk, \\ Fatimanisar07@gmail.com, Kashifsaleem93@gmail.com
}

How to cite this paper: Nawaz, K., Usman, M., Nadeem, M., Nisar, F. and Saleem, K. (2018) Workers Job Satisfaction (a Research on 100 Engineering Workers Are Working in Department of Electrical at Al-Arabia Sugar Mill, Noon Sugar Mill and Shakarganj Sugar Mill Manufacturing Plants in Sugar Industry of Pakistan). American Journal of Industrial and Business Management, 8, 2209-2230.

https://doi.org/10.4236/ajibm.2018.811148

Received: October 17, 2018

Accepted: November 19, 2018

Published: November 22, 2018

Copyright $\odot 2018$ by authors and Scientific Research Publishing Inc. This work is licensed under the Creative Commons Attribution-NonCommercial International License (CC BY-NC 4.0). http://creativecommons.org/licenses/by-nc/4.0/ (c) (i) (8) Open Access

\begin{abstract}
This research paper focused its aim to investigate the consequences of organizational justice and its components on the job satisfaction of engineering workers working in the three different organizations in same sugar industry. This work further contributed to examine the relationships of distributive, procedural and interactional justice with the satisfactory feelings of electrical workers at manufacturing plants of three different organizations. To find out the fact on this topic, three different organizations manufacturing plants engineering workers are specifically working in electrical department. For data collection, a sample of 100 electrical employees is selected randomly. Structured close ended questionnaire is used to collect the data. After completing the process of data collection SPSS is used for data analysis. The output of analysis confirms that organizational justice and its components have perfect positive relationship with the satisfaction level of engineering workers of electrical department. Furthermore, they have positive linkages with engineering workers work satisfaction. It is expected that, this paper will provide fruitful assistance to scholars for further research on the topic of organizational justice and its significant role for employee's job satisfaction.
\end{abstract}




\section{Keywords}

Organizational Justice, Procedural Justice, Distributive Justice, Interactional Justice, Impacts, Co-Relation, Regression, Engineering Employee Job Satisfaction

\section{Introduction}

The collection of people which are working together to attain a common shared goal is called organization. To achieve the goals, organizations are required to satisfy job committed workers. To gain this strategic goal, organizations are investing to develop their human resources. For this instance, managerial excellence and treating of employees at working conditions are getting vital importance. In the intense competition, organizations are facing a huge rate of competition in the market. Because the markets are served by different players so that it is increasing the rate of turnover and opportunities for new jobs are enhanced [1] (Altahayneh, Z. L., Khasawneh, A., \& Abedalhafiz, A. 2014). To gain sustainability in the market and get competitive advantage, retention of satisfied and job committed work force has get a significance importance. Employees want to stay in the organizations where they get fairness in system. They are rewarding according to their contributions in work [2] (Buluc, B., \& Gunes, A. M. 2014). Justice represents the system effectiveness of any organization. The firms have developed systems and integration of activities has more retention ratio of their workers [3] (Bagdadle, Roberson, and Poalele. 2006). Same walk and talk fair performance management system is a significant association with the employee's job satisfaction. The trust of workers on the organization is connected with the degree of justice of the organization. If the organizations have high degree of justice and treated the employees equally, they have more satisfied workforce with respect to others [4] (Dr. Ahmad Raza Bilal, Farwa Muqadas and Sumaira Khalid 2015). Workers get dissatisfaction when they have the mental model that they are not treated equally. The nepotism and unfairness of system produce high turnover ratio and upset workforce [5] (Choong Kwai Fatt, Edward Wong Sek Khin and Tioh Ngee Heng 2010). Organizational justice represents from the acts of leaders and mangers. It is the clear picture of treating the all levels of employees in the same way [6] (Chegini, M. G. 2009). Sharing of incentives and rewards are also important in the working places. If the organization is expanding in the market, but the employees cannot get any opportunities for career therefore they get dissatisfaction. The ultimate cause is decrease in productivity of the organization and high turnover ratio from employees. Organizational justice develops a perception of equality in the in sight of workers.

Employees have more job affinity when they get justice in the activities and process of organization. Justice is decreasing the job insecurity of employees because they are sure not to fire with any biases [7] (Mahboob F and Khan B 2017). 
Satisfaction is directly related to the minds and heart feelings and it is only achieved by providing equal career path and same punishment to employees without ant biasness from the organization. More degree of justice is positively associated with the job satisfaction of labor. When needs are addressed in same context of the employees, they the employees have more affiliation with their organization [8] (Cropanzano, R. \& Rupp, D.E. 2003).

Organizational justice has three components procedural justice, distributive justice, and interactional justice. These are making the justice at any working place. Fairness of whole system of the organization is the called organizational justice [6] (Chegini, M. G. 2009). It the state of thinking of employees about the fairness of the firm is said to be organizational justice [9] (DeConinck, J. B., \& Stilwell, C. D. 2004). How the community of workers has realization about the walk and talk of the company is called justice at organizational level. If the leverage of organizational justice is high, than it is to be considered that other types of justices are fulfilled and employees have better level of satisfaction. This will cause of more retention ratio and low employee turnover. Organizational justice finally leads to the organization towards retainable competitive position in the intense competition. They are in better position to deliver for their customers and able the company for customer retention. Researchers were founded the fact that organizational justice is a weapon for employees satisfaction. Justice becomes cause of work life balance of employees. This justice will make the employees enable to stay in one organization for the long time [10] (Zubair Aslam, Amir Javed 2018).

Different studies were found results about the different components of justice which makes organizational justice finally. Basically distributive justice is related to the conformity of resources and its distribution [11] (Nina D. Cole, Douglas H. Flint 2004). Furthermore, it is associated with the transparency of opportunities of careers for employees, promotion activities, distribution of rewards, and using of performance appraisal system for both developmental and administrative purposes [11] (Nina D. Cole, Douglas H. Flint 2004).

The 2nd component is said to be procedural justice who is connected with the process related to the decision making of organization. What types of decision are making at organizational level and how the fairness is assured? It is also explains the findings of resource to do and execute the business operations [12] (Zeinabadi, H., \& Salehi, K. 2011). The decisions are related to provide the resources to employees for solving the problems and idea implementations [13] (Mumin, Dayan 2008).

The third component which become create the organizational justice is called interactional justice. The communication at working place is effect the job satisfaction of engineering workers. If the working conditions are free from any type of biases like geographic, gender, ethnicity etc. than the bi-lateral communication is increased and employee have feeling of relaxation at working place [8] Cropanzano, R. \& Rupp, D.E. 2003). The organizational justice is described by 
different studies in different ways. Some of those find that employees have inputs in term of education, experience and they want fair praise on their outputs. Employees are being treating in fair way, than they are more promised with their tasks and enhanced the work efficiency [14] (Atif Kafayat, Muhammad Arslan Ali 2014). Justice provides the opportunity to organizations to sustain in the competitive environment for long time. Only satisfied workforce enables the firms to expand in the market and get competitive advantage. Satisfaction and retention of customers only be got by job committed employees. Employees are the ambassador for the firms. They are showing the real face of their organization. Workers have productive and polite behaviors when they are satisfied in their organization [15] (Amin, A., \& Naqvi, I. H. 2014). The satisfaction of job is how a Engineering worker is engaged with his or her job? How much an employee like their works? Justice have positive link with the workers satisfaction in their work. Increase the transparency of performance management system will cause of increasing the job affliction of the employees. When the feedback of jobs are providing on time with honesty to employees increase their trust and engagement with their work and organization [8] (Cropanzano, R. \& Rupp, D.E. 2003).

The major purpose of this research paper is to focus the topic of organizational justice and its components with its association to engineering employee job satisfaction. In this research work, organizational justice and its components are taking as an independent variable whereas; job satisfaction of Engineering Workers is dependent variable. So that, it can be further explore the consequences of $\mathrm{OJ}$ on worker job satisfaction. Finally it is expected that, this paper is providing fruitful information to organizations, scholars and HR consultants about the importance of $\mathrm{OJ}$ and its vital role for the job satisfaction of engineering workers at manufacturing plants. This is also expected that this research paper will share new directions for the organizations of sugar industry on the topic of organizational justice and its relative significance for engineering workers job satisfaction. This research fully focused on the engineering workers working at manufacturing plants of sugar industry. It is also expected that the findings of this research paper can be generalized for other disciplines of engineering workers whose are working at manufacturing plants in same settings.

Structure of paper:

At last, this research start to investigate the impacts of organizational justice on engineering workers jobs satisfaction. Typically, three large organizations manufacturing plants are selected for data collection. Data is collected from the electrical workers. The core purpose is to find the fact that either organizational justice affects the job satisfaction of electrical workers or not. After analysis, the fact is concluded the OJ has significant positive relationship with the job satisfaction of engineering workers of manufacturing plants of sugar industry.

Typically this research paper contains the following contents:

- Introduction \& Significance of research paper;

- Brief literature review; 
- 6 hypotheses to investigate the relationship and effect of OJ on job satisfaction of engineering workers;

- Data collection through questionnaire at manufacturing plants;

- Conclusion;

- Limitations and future research directions.

\subsection{Problem Statement}

This paper is focusing to address the research gape by investigating the "impacts of Organizational justice on engineering employee's job satisfaction". Either the OJ has positive links with workers satisfaction or not, this study can explain and provide facts at the end of analysis.

\subsection{Research Question}

This research work will address the following research questions:

- How Distributive Justice impact on employee job satisfaction?

- How Procedural Justice impact on employee job satisfaction?

- How Interactional Justice impact on employee job satisfaction?

\subsection{Research Objectives}

- To investigate the impact of distributive justice on employee job satisfaction.

- To investigate the impact of procedural justice on employee job satisfaction.

- To investigate the impact of interactional justice on employee job satisfaction.

\section{Literature Review}

\subsection{Organizational Justice}

In today, the environment of market is highly competitive. The business world become too short and technology shrink the distances. In this situation, the workers which are working in any organization are educated and much aware about their rights. It is the nature of humanity that to find equality and respect. The 21th century has been going on and employees have more working opportunities across the globe. Today firms understand the strategic value of their human resources. They find the fact that they are only at dominance position in the market with the help of their human capital. Thus the discussion about the topic of organizational justice gets significant importance. $\mathrm{OJ}$ is associated with the walk and talk of leaders and management. It is basically the set of promises which makes an organization with their human capita. Some of the scholars describe it as governance of management by equal policies [11] (Nina D. Cole, Douglas H. Flint 2004). Different researchers associate the linkages of different aspects of justice with the well being of workers. Some researchers cited the positive association of $\mathrm{OJ}$ with employee job satisfaction. Rules are generals and for all at working place [12] (Zeinabadi, H., \& Salehi, K. 2011). Equality minimizes the class struggle in workers against the management. The behaviors of management and low degree of equal career opportunities at working environment 
will create insatiability in the organizations [2] (Buluc, B., \& Gunes, A. M. 2014). Pay the people monetary and non-monetary term fairly according to their performance will increase mental satisfaction of workers. It will cause of organization citizenship behavior [4] (Dr. Ahmad Raza Bilal, Farwa Muqadas and Sumaira Khalid 2015). All human have different types of necessities but foremost after living is to get respect and praise on work. In the contribution of employees is neglected by the administration than it will finally affect the moral of employee and they do not want more stay in the organization. The organizations which are providing praise to their employees and gives appreciation towards their efforts for organization, such organization have low employee turnover ratio and high employee job commitment [12] (Zeinabadi, H., \& Salehi, K. 2011). Organizational justice better is explaining by the decisions making operations of the management. If they have no holy cow and all workers have same way of treatment according to one policy hence it will enhance the moral capital of the organization. The employees who are serving at low level will get confidence and their satisfaction with wok increased. For achieving the goal of employees' job satisfaction, than developed the working conditions and working hours. By providing balance in the life of worker, boots up their commitment with organization. The employees who have less degree of stress from the organization have more degree of work satisfaction [16] (Muhammad Umair akram, Muhammad Hasim, Zubair akram 2015).

\subsection{Components of Organizational Justice}

\section{Procedural Justice}

Organizational justice is the integration of some elements like that procedural justice. It is basically the transparency of process which is connected with decision making. The complexity with this aspect of organizational justice is that it's deeply connected with the fairness of process and activities which are being performing. The factors which are considering measuring the Procedural justice like performance management system of organization and appraisal system and degree of person-organization fit [17] (Kamran Nawaz, Mudassar Usman 2018). Act of the organization and the decisions of management are spoken loudly than the written rules and policies. If the organization has no dissonance in written material and its activities at working place so employees trust on the decisions will increase [13] (Mumin, Dayan 2008). If workers are observing that decisions are continuous and free from any biasness than the implementation phase is easy for complex decisions. Rule the working by keeping ethics in consideration will improve the motivation of workers with their tasks. The organization which are free from the biases of gender, ethnicity etc. their employees have low level of stress and misfit at working environment [12] (Zeinabadi, H., \& Salehi, K. 2011). When management take an important decision, than it is necessary to get consideration of employees. The participation of employees is increase the quality of implementation phase. Organization has opportunity to answer the workers on their suggestions at the time of discussion in case of any failure. Firms must have 
capability to address the actual needs of their workers in their strategic decision making process. Company decisions about the career path must be fair and it is highly related with the satisfaction of employees [2] (Buluc, B., \& Gunes, A. M. 2014). The process of decision making is transparent and free of any nepotism. In case of such issues when management takes decisions in favor of their biases, it will defame the other positive steps of organization. If the decisions of the organization is moving smoothly and treating the human resource as an asset so it will affect the satisfaction of employees in favorable way. Such type of organization has no job quit ratio and more task commitment [16] (Muhammad Umair akram, Muhammad Hasim, Zubair akram 2015). Findings from different studies confirm the positive repercussions of procedural justice on the satisfaction of employees. After talking those facts into account, this research work is going to formulate the following research hypothesis:

$\mathrm{H1}$ : There is a positive relationship between procedural justice and job satisfaction.

$\mathrm{H} 2$ : There is a positive impact of procedural justice on job satisfaction.

\subsection{Distributive Justice}

The 2nd component which develops the organizational justice is said to be distributive justice. This element is related with the activities and operation of organization associated with allocation and distribution of resources. Furthermore, the DJ holds the activities which are in the domain of performance management system. The development of performance system, setting of evaluating criteria, using of feedback after getting respond from employees are the part of distributive justice. The process of providing awards to employees according to their contribution in work is called DJ [18] (Chang, E. 2002). Distributive justice enables comparison $b / w$ the work performance of individuals. If the feedback is gathering honestly and will share according to the soul of performance management system than in results it will move forward the level of satisfaction of employees with the work and organization [11] (Nina D. Cole, Douglas H. Flint 2004). The equality in promotions opportunities at working place to employees has positive consequences on job satisfaction of workers. When the employee of an organization observe that they have career path according to their hard work therefore they are feeling relax and satisfied with organization [19] (Anat R., and Monica W., 1999). Strategically investment on employees for their career development, education enhancement, training and development will always affect positively on the job satisfaction of employees. When the working of any company understand that they are invested by organization and the whole profit is not going towards the owners than the leaving ratio of jobs in the organization is minimized [9] (DeConinck, J. B., \& Stilwell, C. D. 2004). Fulfillment of needs and minimize the degree of dissonance in defying the needs $b / w$ the organization and employees increasing the job interest of workers. If the workers have more interest in the work so that it is enhanced the degree of outcome [20] 
(Ghafoor, A., Qureshi, T. M., Khan, M. A., \& Hijazi, S. T. 2011). The analysis of different papers and journals found the positive reasons of distributive justice towards the job motivation of employees. Fair rewards affiliating by the organization to its employees has positive connections with individual's job satisfaction [21] (Ismail Nizam 2016). Control on resources and related utilization decisions increase the job satisfaction of desired level of employees. The employees which are working at top levels of the organization have needed to decide about the allocation and distribution of resources. If the organization fulfills this need fairly than the job commitment is increased [13] (Mumin, Dayan 2008). The following research hypothesis is suggested for testing:

H3: There is a positive relationship between distributive justice and job satisfaction.

H4: There is a positive impact of distributive justice on job satisfaction.

\subsection{Interactional Justice}

The 3rd component which is being investigated in this research work is called interactional justice. It is also a form of justice which finally cause of organizational justice. It is degree of effectiveness of decisions taken by management. How much the decisions are affected the employees and how much these are taken with clarity [9] (DeConinck, J. B., \& Stilwell, C. D. 2004). IJ represent the degree of ideal communication at working place. Is the working conditions are free of barriers? [17] (Kamran Nawaz, Mudassar Usman 2018). The organizations which have low barriers at working place and the communication $\mathrm{b} / \mathrm{w}$ employees is at greater domain, the workers of such firms have low stress and better understanding of tasks. It is due to workers are able to discuss their issues with other employees so that they get assistance and satisfied from working environment [17] (Kamran Nawaz, Mudassar Usman 2018). There is quite difference $\mathrm{b} / \mathrm{w}$ the work and organization satisfaction. Different researchers have found the analysis that there is a chance that someone is satisfied with his work but not satisfied in the organization. If the individuals have clear understanding of tasks than his/her performance is increased but it does not mean same individuals are also satisfied with the company [17] (Kamran Nawaz, Mudassar Usman 2018). High degree of communication will decrease the degree of conflicts at working environment [21] (Ismail Nizam 2016). When there is no resistance in communication $\mathrm{b} / \mathrm{w}$ the workers so that it will affect positively and cause of developing social bonds. It will boot up the leverage of relationships b/w the workers. These factors assure the long stay and high job satisfaction of employees [21] Ismail Nizam (2016). The high rate of communication $b / w$ the workers and management will have positive consequences on the satisfaction of workers. It will enhance the trust of employees on management and remove some sort of small issues. The organizations in which employees have a proper platform to discuss their issues in front on management on desired level so they are not going to join the unions against administration [16] (Muhammad Umair akram, Mu- 
hammad Hasim, Zubair akram 2015). When an organization is developed a bias free working environment than the communication and co-ordination is improved and positively connected with workers job satisfaction. After reviewing the findings of previous studies this research work is formulated the following hypothesis:

H5: There is a positive relationship between interactional justice and job satisfaction.

H6: There is a positive impact of interactional justice on job satisfaction.

\subsection{Job Satisfaction}

There are many factors which affecting the job satisfaction of employees at working place. This research work focusing the rate of change in justice and its impacts on the workers job satisfaction. Studies suggested that the theocracy of impacts of decisions in more important and considerable variable in social sciences but not too important in the field of physical sciences [5] (Choong Kwai Fatt, Edward Wong Sek Khin and Tioh Ngee Heng 2010). After the life and security needs, the need of money is the basic purpose of doing the jobs. If an individual is earning according to his basic needs than he will satisfy with his job and continue its doing. But if he has low payments with respect to market, so he will try to leave his jobs. So we can said that rate of paying pay also an influential factor for the job satisfaction of workers [4] (Dr. Ahmad Raza Bilal, Farwa Muqadas and Sumaira Khalid 2015). The degree of available career opportunities in the organization and fair way of selection is also associated with the job satisfaction of employees. If the skilled workers observe that they have no future whether they put too many efforts so they become pessimists from the organization and decide to leave. Such organizations have high rate of turnover where employees have low career chances [9] (DeConinck, J. B., \& Stilwell, C. D. 2004). The small organizations whose have not a developed performance management system for the evaluation of employees so that different studies found the fact they have low satisfaction of employees and high rate of turnover. Whether such type of organizations have better communication and satisfy the condition of interactional justice, but the fact is that overall organizational justice is low. Therefore, the fulfillment of any one form of justice is not enough; organizations need to move towards organizational justice to gain the satisfaction of their labor force [22] (Fernandes, C. and Awamleh, R. 2006). The behaviors of managers and supervisors also associated with the job satisfaction of employees. If the managers of an organization are showing respect towards the workers, their acts are bias free, they evaluated the performance of employees honestly, than the co-workers trust will increased and this will move forward the job satisfaction of workers [3] (Bagdadle, Roberson, and Poalele. 2006). Job satisfaction represents the intentions of employees towards their jobs. If the employees shows more interests in doing the tasks and their performance is also satisfactory will be concluded that such workers has high degree of satisfaction with his job [23] (Am- 
brose, Maureen; Hess, Ronald L.; Ganesan, Shankar 2007). At the end we can discuss the fact that organizational justice has strong positive link with the job satisfaction of employees which is investing in this work also. But it is also considerable fact found in literature that there are some other factors also which play a vital role for the job satisfaction of employees. Others researches works also may be discussed or will discuss these factors.

\section{Methodology}

All Engineering Workers of electrical department's are the member of this research study. The facts are collected from B.tech, B.Sc, BS and MS in electrical. The reason behind choosing this sample is due to present research paper specifically focused on engineering workers working on manufacturing plants. The data is collected through questionnaires from one hundred electrical employees of three different sugar cane organizations. A questionnaire is design by using previous literature reviews with some modifications. It consist 23 items regarding the dimensions of the three facts of organizational justice i.e., distributive, procedural and interactional and of job satisfaction. Distributive, procedural and interactional and of job satisfaction have 5, 6, 7 and 5 items respectively. Distributive justice, procedural justice and interactional justice are being measured through 18 items scale developed by [24] (Neihoff and Moorman 1993). The value of alpha for this scale in western studies was $0.99,0.90$, and 0.90 respectively. The reliability value in that study was $0.79,0.82$ and 0.80 respectively. The degree of job satisfaction of Engineering Workers is measuring by using 5 items scale developed by [22] (Fernandes, C. and Awamleh, R. 2006). The value of alpha for western studies was 0.87 . The relative value of reliability for job satisfaction was 0.83 . A 5-point Likert scale is used that distinguish the people opinions ranging from "strongly agree" to "strongly disagree" relating to the questionnaire items as being observed in their particular sector.

\subsection{Sample Size and Sampling Technique}

The sample size of this study is 100 respondents working in three different sugar cane organizations names as Al-Arabia sugar mill, Noon sugar mill and Shakarganj sugar mill manufacturing plants. This research paper associated with its core aim to explore the impact of $\mathrm{OJ}$ on engineering workers job satisfaction. Due to this reason, a sample of 100 electrical workers is taking. These all employees are working in department of electrical in their organizations. Random sampling technique is used for data collection. The respondents must be full-time employee and have minimum 2 years of work experience in the organization.

\subsection{Data Collection and Data Analysis}

The survey questionnaire is distributed among the electrical employees after obtaining prior approval from the relevant authority of the organization. Data are 
collected once they have completed the questionnaires. By using SPSS, these are the analysis which done like descriptive statistics, reliability measures; multiple correlation and regression to test the study hypotheses.

\subsection{Result}

In this research Figure 1 shows model for research respondent which be shown in Table 1 and Figure 2. Sample size is taking to complete this research is 100.

Result shows three levels of educational levels (Bachelor, Graduate and Post graduate). The feedback which being covered id demonstrated in Table 2 and Figure 3. Bachelor are 19\%, Graduate $49 \%$ and Post Graduate are 32\%.

Respondent are dividing into four groups of age (21 - 30, 31 - 40, 41 - 50, and $51-60)$ for talking their respond on questionnaire. The results are describing the age domain in Table 3 and Figure 4.

Mean is defined as a central point of data. Table 4 showed the mean \& standard deviation for whole organizational justice and job satisfaction. The mean score of distributive justice is 15.95 , procedural justice is 17.95 , interactional justice is 25.80 and job satisfaction is 16.30. Result showed that most of respondent were agree that organizational justice have more impact on job satisfaction. Employee will more satisfy if high degree of organizational justice will exists.

Table 5 summarized that $\alpha$-reliability statistic of the instruments used in the study for testing the variables. Table 5 shows that Chronbach's $\alpha$ value for distributive justice is 0.704 . Similarly, Chronbach's a value of 0.719 for procedural justice and the value of interactional justice is 0.737 and cronbach's value for job satisfaction is 0.761 .

Table 6 shows the co-relation. Co-relation is the degree of relationship b/w two variables. The range of relationship is from 1 to -1 . 0 describe that no

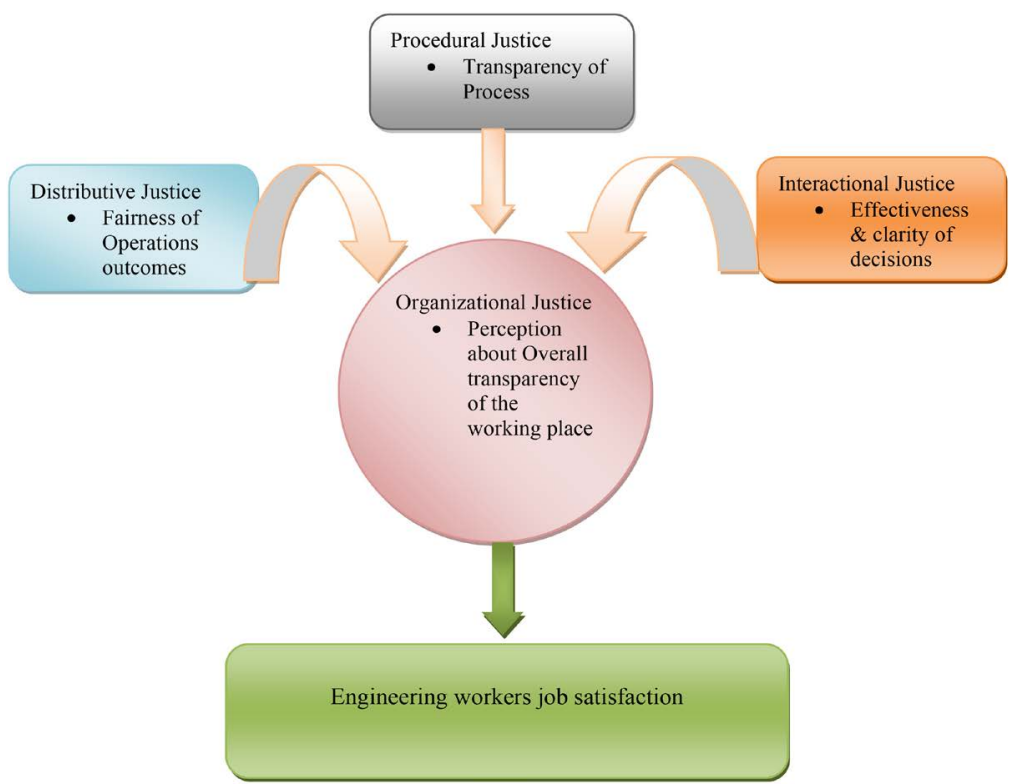

Figure 1. The model for research. 


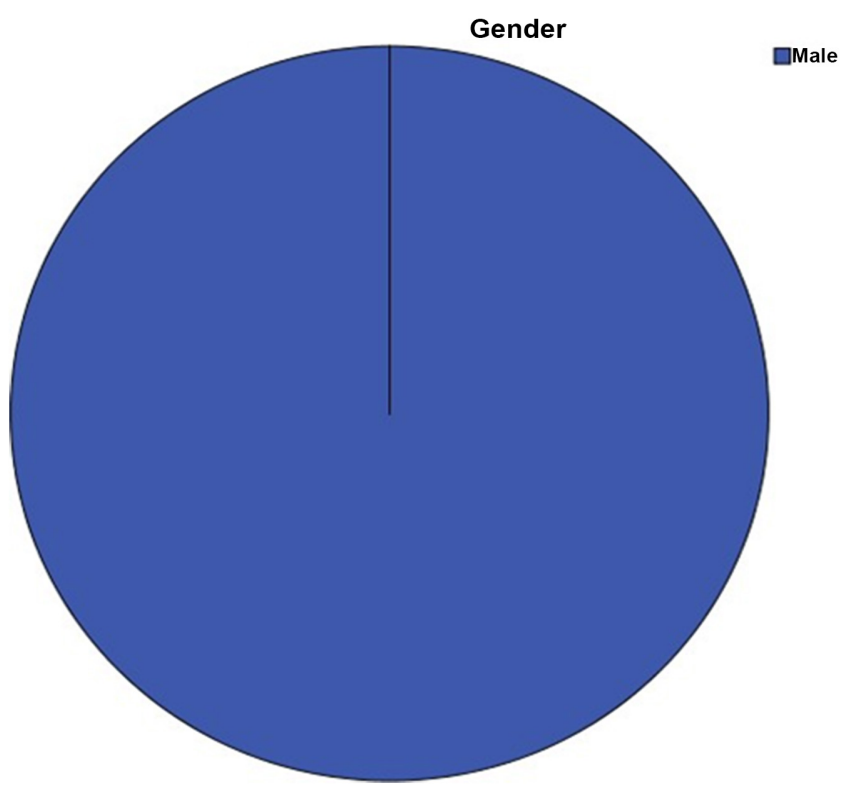

Figure 2. Gender ratio.

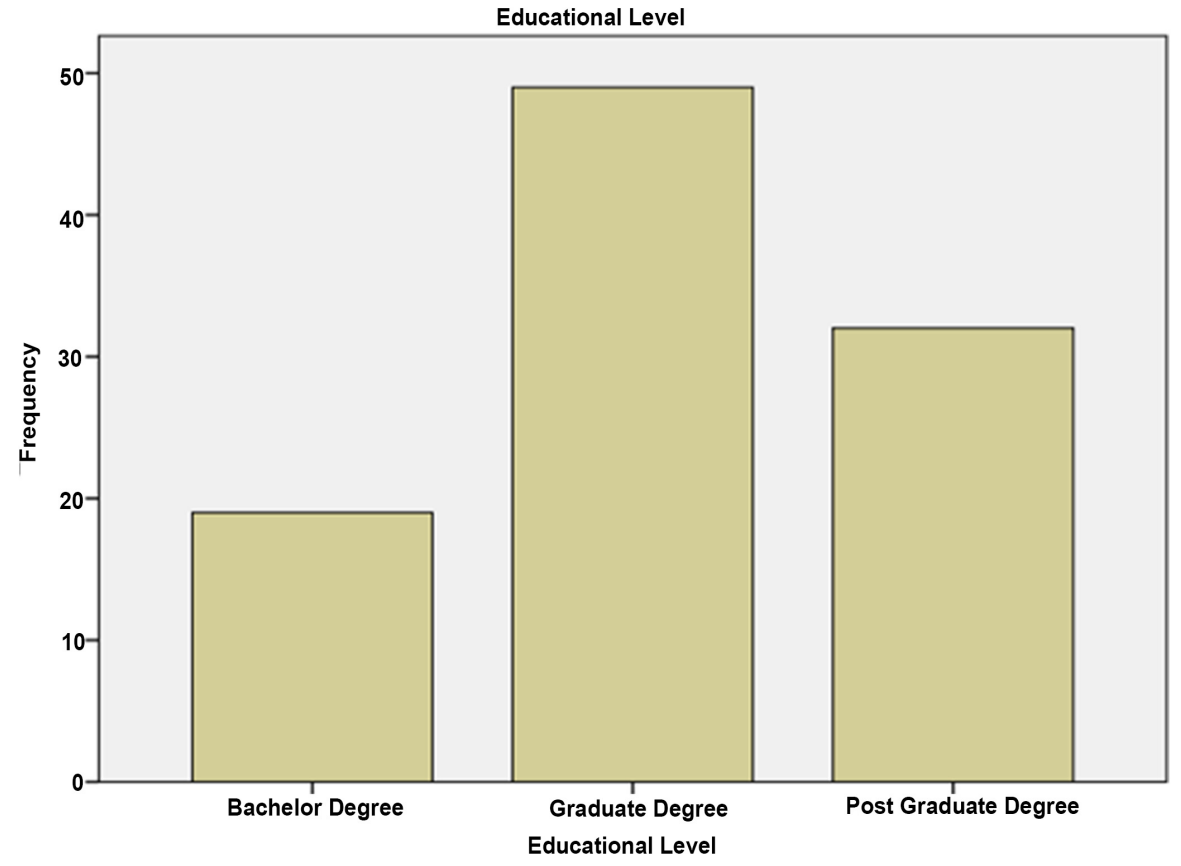

Figure 3. Education level.

relation is exist $\mathrm{b} / \mathrm{w}$ the variables. In mentioned table, the results show strong positive relationship organizational justice and job satisfaction of employees. Distributive justice has strong positive relationship with job satisfaction the value is $0.411^{* *}$. Similarly procedural justice value is $0.319^{* *}$ and interactional justice value is $0.551^{\star *}$.

$\mathrm{R}$ value represent the leverage of relationship $\mathrm{b} / \mathrm{w}$ the variables. The values in Table 7 describing that it comes from 0.41 to 0.55 . It is clarifying the fact that organizational justice hold strong positive relation with job satisfaction. 


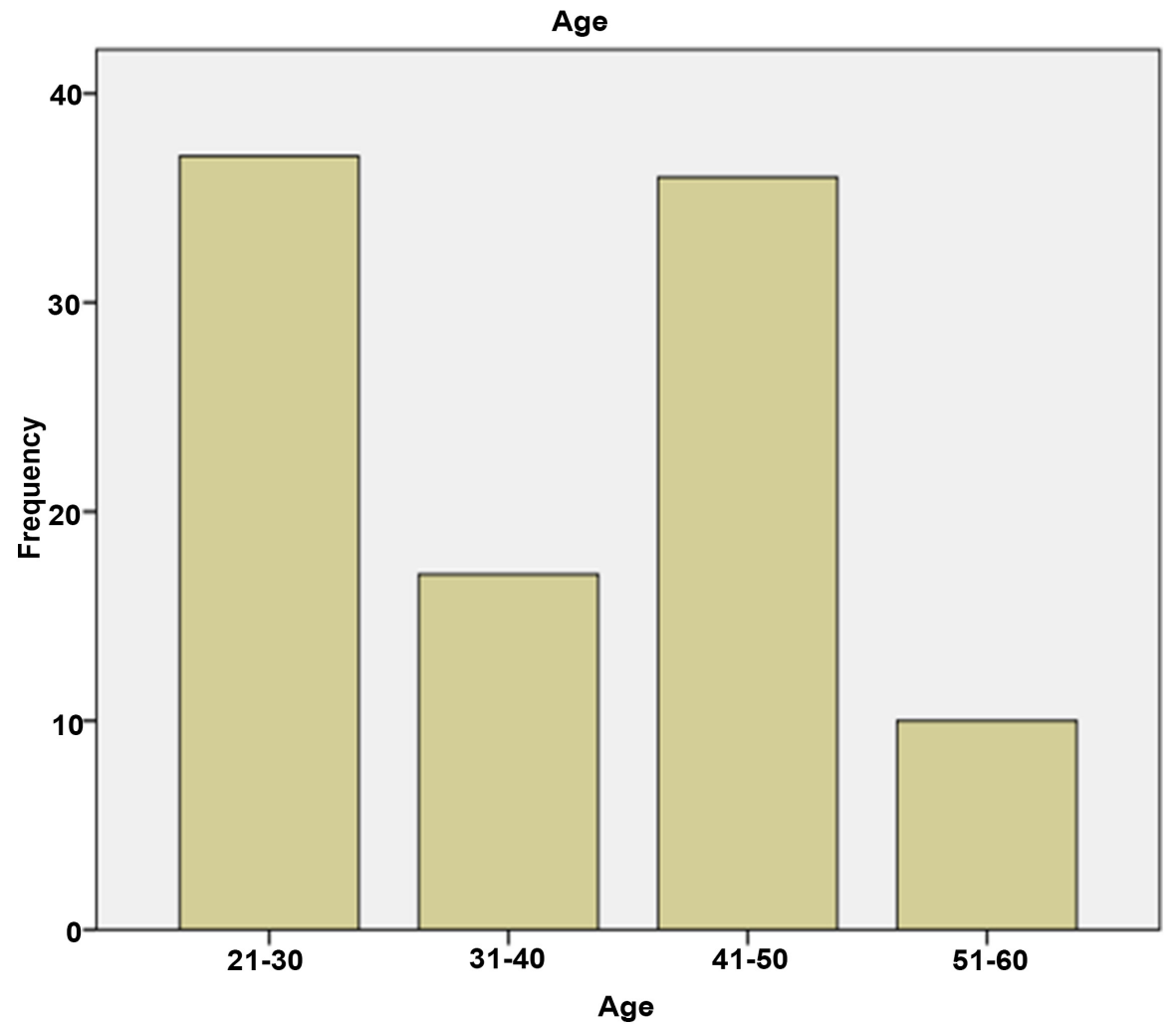

Figure 4. Ages of respondents.

Table 1. Gender ratio.

\begin{tabular}{cccccc}
\hline & & Frequency & Percent & Valid Percent & Cumulative Percent \\
\hline Valid & Male & 100 & 100.0 & 100.0 & 100.0 \\
\hline
\end{tabular}

Table 2. Education level.

\begin{tabular}{|c|c|c|c|c|c|}
\hline \multicolumn{2}{|r|}{ Education level } & \multirow{2}{*}{$\begin{array}{c}\text { Frequency } \\
19\end{array}$} & \multirow{2}{*}{$\begin{array}{c}\text { Percent } \\
19.0\end{array}$} & \multirow{2}{*}{$\begin{array}{c}\text { Valid Percent } \\
19.0\end{array}$} & \multirow{2}{*}{$\begin{array}{c}\begin{array}{c}\text { Cumulative } \\
\text { Percent }\end{array} \\
19.0\end{array}$} \\
\hline & Bachelor Degree & & & & \\
\hline \multirow{3}{*}{ Valid } & Graduate Degree & 49 & 49.0 & 49.0 & 68.0 \\
\hline & Post Graduate Degree & 32 & 32.0 & 32.0 & 100.0 \\
\hline & Total & 100 & 100.0 & 100.0 & \\
\hline
\end{tabular}

Table 3. Ages of respondents.

\begin{tabular}{cccccc}
\hline Age & Frequency & Percent & Valid Percent & Cumulative Percent \\
\hline $21-30$ & 37 & 37.0 & 37.0 & 37.0 \\
& $31-40$ & 17 & 17.0 & 17.0 & 54.0 \\
Valid & $41-50$ & 36 & 36.0 & 36.0 & 90.0 \\
& $51-60$ & 10 & 10.0 & 10.0 & 100.0 \\
\hline
\end{tabular}


Table 4. Means and standard deviation of organizational justice.

\begin{tabular}{ccccccc}
\hline Variable & Range & Minimum & Maximum & Mean & Std. Deviation & Variance \\
\hline Distributive Justice AV & 16.00 & 8.00 & 24.00 & 15.9500 & 3.34354 & 11.179 \\
Procedural Justice AV & 16.00 & 11.00 & 27.00 & 17.9500 & 3.69650 & 13.664 \\
Interactional Justice AV & 26.00 & 13.00 & 39.00 & 25.8000 & 4.27820 & 18.303 \\
Job Satisfaction AV & 16.00 & 9.00 & 25.00 & 16.3000 & 3.53768 & 12.515 \\
\hline
\end{tabular}

Table 5. Reliability statistics.

\begin{tabular}{ccc}
\hline Variable Name & Cronbach's Alpha & N of Items \\
\hline Distributive Justice & 0.704 & 5 \\
Procedural Justice & 0.719 & 6 \\
Interactional Justice & 0.737 & 7 \\
Job Satisfaction & 0.761 & 5
\end{tabular}

Table 6. Correlation analysis.

\begin{tabular}{ccccc}
\hline Variable Name & DJAV & PJAV & IJAV & JSAV \\
\hline DJAV Pearson Correlation & 1 & $0.618^{* *}$ & $0.362^{* *}$ & $0.411^{* *}$ \\
PJAV Pearson Correlation & & 1 & $0.413^{* *}$ & $0.319^{* *}$ \\
IJAV Pearson Correlation & & 1 & $0.551^{* *}$ \\
JSAV Pearson Correlation & & & & 1 \\
\hline
\end{tabular}

Table 7. Model summary for regression.

\begin{tabular}{ccccc}
\hline Model & $\mathrm{R}$ & R Square & Adjusted R Square & Std. Error of the Estimate \\
\hline Distributive justice & $0.411 \mathrm{a}$ & 0.169 & 0.161 & 3.06333 \\
Procedural justice & $0.319 \mathrm{a}$ & 0.102 & 0.092 & 3.52168 \\
Interactional justice & $0.551 \mathrm{a}$ & 0.303 & 0.296 & 3.58948 \\
\hline
\end{tabular}

(Table 8) ANOVAa is the degree of fitness of testing model. $\mathrm{F}$ value shows the fitness of table. The values of $\mathrm{F}$ for all variables are showing in the table describing the fitness of this research work.

Regression is defined as the degree of effectiveness of independent variable on dependent variable. Table 9 shows the positive relationship between organizational justice and job satisfaction. DJ, PJ and IJ are independent variable and job satisfaction is dependent variable. Result shows that if there is one unit change in distributive justice than it would change $41.1 \%$ increase in employee job satisfaction. Result shows the positive relationship between dependent and independent variables.

Table 10 shows the relationship between procedural justice and job satisfaction. Procedural justice effect to job satisfaction, if degree of procedural justice 
Table 8. ANOVA statistics.

\begin{tabular}{cccccc}
\hline Model & Sum of Squares & Df & Mean Square & F & Sig. \\
\hline DJ Regression & 187.120 & 1 & 187.120 & 19.940 & $0.000 \mathrm{~b}$ \\
PJ Regression & 137.334 & 1 & 137.334 & 11.073 & $0.001 \mathrm{~b}$ \\
IJ Regression & 549.334 & 1 & 549.334 & 42.636 & $0.000 \mathrm{~b}$ \\
\hline
\end{tabular}

Table 9. Regression for distributive justice.

\begin{tabular}{|c|c|c|c|c|c|c|c|c|}
\hline & \multirow{2}{*}{ Model } & \multicolumn{2}{|c|}{$\begin{array}{l}\text { Un Standardized } \\
\text { Coefficients }\end{array}$} & \multirow{2}{*}{$\begin{array}{c}\text { Standardized } \\
\text { Coefficients } \\
\text { Beta }\end{array}$} & \multirow{2}{*}{$\mathrm{t}$} & \multirow{2}{*}{ Sig. } & \multicolumn{2}{|c|}{$\begin{array}{c}95.0 \% \text { Confidence } \\
\text { Interval for B }\end{array}$} \\
\hline & & B & Std. Error & & & & $\begin{array}{l}\text { Lower } \\
\text { Bound }\end{array}$ & $\begin{array}{l}\text { Upper } \\
\text { Bound }\end{array}$ \\
\hline \multirow{2}{*}{1} & (Constant) & 9.615 & 1.451 & & 6.626 & 0.000 & 6.736 & 12.495 \\
\hline & JSAV & 0.389 & 0.087 & 0.411 & 4.465 & 0.000 & 0.216 & 0.561 \\
\hline
\end{tabular}

Table 10. Regression for Procedural justice.

\begin{tabular}{|c|c|c|c|c|c|c|c|c|}
\hline & \multirow{3}{*}{ Model } & \multirow{2}{*}{\multicolumn{2}{|c|}{$\begin{array}{l}\text { Un Standardized } \\
\text { Coefficients }\end{array}$}} & \multirow{3}{*}{$\begin{array}{c}\text { Standardized } \\
\text { Coefficients } \\
\text { Beta }\end{array}$} & \multirow{3}{*}{$\mathrm{T}$} & \multirow{3}{*}{ Sig. } & \multicolumn{2}{|c|}{$\begin{array}{c}95.0 \% \text { Confidence } \\
\text { Interval for B }\end{array}$} \\
\hline & & & & & & & \multirow{2}{*}{$\begin{array}{l}\text { Lower } \\
\text { Bound }\end{array}$} & \multirow{2}{*}{$\begin{array}{l}\text { Upper } \\
\text { Bound }\end{array}$} \\
\hline & & B & Std. Error & & & & & \\
\hline \multirow[t]{2}{*}{1} & (Constant) & 12.523 & 1.668 & & 7.506 & 0.000 & 9.212 & 15.834 \\
\hline & JSAV & 0.333 & 0.100 & 0.319 & 3.328 & 0.001 & 0.134 & 0.531 \\
\hline
\end{tabular}

high than employees is more satisfied because it relationship is positive. Changes in procedural justice will affect $31.9 \%$ increase in employee job satisfaction.

The above mentioned three tables are holding three different values for beta. It means that change in independent variable affect the dependent variable in respective way respectively. For the last Table 11 of interactional justice hold the beta value of $0.55 \%$ that means IJ affect the job satisfaction in this ratio. It relation is positive.

\subsection{Discussion on Results}

The research model revealed important findings regarding impact of organizational justice on job satisfaction. By comparing these results with previous studies the fact become clear that the organizational justice has positive link with the job satisfaction of employees. This present revealed that organizational justice has positive impact on the college employee's job satisfaction. It mean if employees find the level of existence of organizational justice in the organization then employee feels more satisfied in term of pay, rewards, decision etc. Result proved that employee were more satisfied when they perceived their outcomes and rewards to be rational as compared to those employees who consider their reward and outcomes as unfair. If employee feels unhappiness regarding their reward they may decide to leave the organization [25] (Sieger, P., Bernhard, F., 
Table 11. Regression for Interactional justice.

\begin{tabular}{|c|c|c|c|c|c|c|c|c|}
\hline & \multirow{2}{*}{ Model } & \multicolumn{2}{|c|}{$\begin{array}{l}\text { Un standardized } \\
\text { Coefficients }\end{array}$} & \multirow{2}{*}{$\begin{array}{c}\text { Standardized } \\
\text { Coefficients } \\
\text { Beta }\end{array}$} & \multirow{2}{*}{$\mathrm{t}$} & \multirow{2}{*}{ Sig. } & \multicolumn{2}{|c|}{$\begin{array}{l}95.0 \% \text { Confidence } \\
\text { Interval for B }\end{array}$} \\
\hline & & B & Std. Error & & & & $\begin{array}{l}\text { Lower } \\
\text { Bound }\end{array}$ & $\begin{array}{l}\text { Upper } \\
\text { Bound }\end{array}$ \\
\hline \multirow{2}{*}{1} & (Constant) & 14.946 & 1.701 & & 8.789 & 0.000 & 11.572 & 18.321 \\
\hline & JSAV & 0.666 & 0.102 & 0.551 & 6.530 & 0.000 & 0.463 & 0.868 \\
\hline
\end{tabular}

\& Frey, U. 2011). If the employees are treating in the working environment fairly they are much motivated and work satisfied [12] (Zeinabadi, H., \& Salehi, K. 2011). There is positive significant relationship found in this study $b / w$ organizational justice and job satisfaction. The researchers found the positive consequences of organizational justice with employee work satisfaction. It is due to employees have more career path is available in such type of organizations [7] (Mahboob F. and Khan B. 2017). When the workers have better control on resources and firm is evaluating the individual's performance with clarity. As a result, firm employees are more satisfied with respect to others. The results are not different and surprising because they are also second the past researches. Most of past studies results are consistent with our research findings. The findings of our research is consistent with across the globe research on this topic in different settings enhanced the creditability of this paper. It is due to it is the nature of humanitarian that they want justice in each and every setting. But some factors are important to consider when doing research on this topic. Person-organization fit is a systematic approach of organization for selection of related employees for work affects procedural justice as well. If an employee is selected wrongly for work or an un-related person is chooses for work then the element of fairness evaluation neglected [17] (Kamran Nawaz, Mudassar Usman 2018). Impact of Organizational justice on job satisfaction is positive where organizational justice is more employees' job satisfaction.

\section{Conclusion and Recommendation}

This study defines employee's perception about organizational justice in the form of (Distributive justice, procedural justice and Interactional justice) and defines its impact on engineering employee job satisfaction on manufacturing plants three at sugar cane mills. Distributive justice, procedural justice and interactional justice are being measured through 18 items scale developed by [24] Neihoff and Moorman (1993). The degree of job satisfaction of engineering workers is measuring by using 5 items scale developed by [22] (Fernandes, C. and Awamleh, R. 2006). This research paper confirms that there is significant positive relationship between distributive justice, procedural justice, interactional justice and job satisfaction of Engineering Workers of department of Electrical. As correlation and regression analysis shows positive relationship with distributive justice, procedural justice and interactional justice so it accepts $\mathrm{H1}, \mathrm{H} 2$, $\mathrm{H} 3, \mathrm{H} 4, \mathrm{H} 5$ and $\mathrm{H} 6$ which are proved in results. If the organization have high 
degree of organizational justice, the employees of the organization have more job satisfaction.

This paper recommended for the management of sugar cane mills to focus on the improvement of organizational justice because human capital is one of the most important factors for the success of any organization and this paper also recommended the major role of organizational justice for the job satisfaction of engineering workers.

\section{Limitations and Future Research Directions}

This research paper has some limitations also that should be focused. First of all, the data is collected only from three sugar cane mills manufacturing plants workers of department of electrical. There is the probability that some results may be vary from department to department. The second limitation for this research paper is that sample size is also not too large. If any other research on same topic with a large sample size may be have some different results. This study consists of three types of justice which are (procedural, distributive and interactional) for the job satisfaction of engineering workers. The third limitation which cannot be neglected that there are some others factors also like person-organization fit it is very necessary at any working place, without providing $\mathrm{P}-\mathrm{O}$ fit employees are not creative. When employees are not performing according to assign task, their level of job satisfaction will decrease [17] (Kamran Nawaz, Mudassar Usman 2018). Without healthy and co-operative working conditions employees are not satisfied with their job [8] (Cropanzano, R. \& Rupp, D.E. 2003). Performance management system is vital role for the job satisfaction of engineering workers of manufacturing plants. If organization not providing feedback accurately and timely so workers become dissatisfied from the job [15] (Amin, A., \& Naqvi, I. H. 2014). Beyond of these limitations, this research paper confirms the relationship b/w organizational justice and job satisfaction of engineering workers. It also finds the fact that organizational justice positively affects the job satisfaction of engineering workers.

\section{Acknowledgements}

First of all, thanks to mercy of Allah almighty by blessing of good health so that this research work is completed. This research paper is not on there without the honest prayers of my parents and family members. My special Gratitude towards Engr. Ghulam Murtaza Qamar Head of Department, Collage of Engineering and Technology University of Sargodha for their fruitful assistance to completing this work. This research work did not receive any grant from any public, private or any nonprofit organization. At last but most important, I would like to thanks my friends and colleagues for their affection.

\section{Conflicts of Interest}

The authors declare no conflicts of interest regarding the publication of this paper. 


\section{References}

[1] Altahayneh, Z.L., Khasawneh, A. and Abedalhafiz, A. (2014) Relationship between Organizational Justice and Job Satisfaction as Perceived by Jordanian Physical Education Teachers. Asian Social Science, 10, 131.

[2] Buluc, B. and Gunes, A.M. (2014) Relationship between Organizational Justice and Organizational Commitment in Primary Schools. The Anthropologist, 18, 145-152. https://doi.org/10.1080/09720073.2014.11891530

[3] Masterson, S.S., Lewis, K., Susan, M. and Goldman, B.M. (2006) Integrating Justice and Social Exchange: The Differing Effects of Fair Procedures and Treatment on Work Relationships. Academy of Management Journal, 43, 738-748.

[4] Bilal, A.R., Muqadas, F. and Khalid, S. (2015) Impact of Organizational Justice on Job Satisfaction with Mediating Role of Psychological Ownership. Global Management Journal for Academic \& Corporate Studies, 5, 63-74.

[5] Fatt, C.K., Khin, E.W.S. and Heng, T.N. (2010) The Impact of Organizational Justice on Employee's Job Satisfaction: The Malaysian Companies Perspectives. American Journal of Economics and Business Administration, 2, 56-63. https://doi.org/10.3844/ajebasp.2010.56.63

[6] Chegini, M.G. (2009) The Relationship between Organizational Justice and Organizational Citizenship Behavior. American Journal of Economics and Business Administration, 1, 173. https://doi.org/10.3844/ajebasp.2009.173.176

[7] Mahboob, F. and Khan, B. (2017) Organizational Justice and Its Impact on Job Satisfaction in Public Sector Universities of Peshawar. Arabian Journal of Business and Management Review, 7.

[8] Cropanzano, R. and Rupp, D.E. (2003) An Overview of Organizational Justice: Implication for Work Motivation. In: Porter, L.W., Bigley, G.A. and Steers, R.M., Eds., Motivation and Work Behavior, McGraw-Hill Irwin, Burr Ridge, IL, 82-95.

[9] DeConinck, J.B. and Stilwell, C.D. (2004) Incorporating Organizational Justice, Role States, Pay Satisfaction and Supervisor Satisfaction in a Model of Turnover Intentions. Journal of Business Research, 57, 225-231. https://doi.org/10.1016/S0148-2963(02)00289-8

[10] Aslam, Z. and Javed, A. (2018) Effect of Organizational Justice on Job Satisfaction in Universities of Pakistan. Journal of Business \& Financial Affairs, 7, 338.

[11] Cole, N.D. and Flint, D.H. (2004) Perceptions of Distributive and Procedural Justice in Employee Benefits: Flexible versus Traditional Benefit Plans. Journal of Managerial Psychology, 19, 19-40. https://doi.org/10.1108/02683940410520646

[12] Zeinabadi, H. and Salehi, K. (2011) Role of Procedural Justice, Trust, Job Satisfaction, and Organizational Commitment in Organizational Citizenship Behavior (OCB) of Teachers: Proposing a Modified Social Exchange Model. Procedia-Social and Behavioral Sciences, 29, 1472-1481.

https://doi.org/10.1016/j.sbspro.2011.11.387

[13] Mumin, D. (2008) The Role of Procedural Justice in the New Product Development Process. European Journal of Innovation Management, 11, 1460-1060.

[14] Kafayat, A. and Ali, M.A. (2014) Effect of Organizational Justice and Job Satisfaction on Organizational Effectiveness with the Moderating Role of Strategic Commitment. Acta Universitatis Danubius. Administratio, 6, 30-41.

[15] Amin, A. and Naqvi, I.H. (2014) The Impact of Institutional Structure on Organizational Effectiveness: Considering Organizational Justice as a Mediator. Organizational Behaviour, 72, 25544-25547. 
[16] Akram, M.U., Hasim, M. and Akram, Z. (2015) Ninth International Conference of Management Science and Engineering Management. 771-779.

[17] Nawaz, K. and Usman, M. (2018) Impact of Person-Organization Fit on Employee Creativity. Arabian Journal of Business and Management Review, 8, Article ID: 1000365.

[18] Chang, E. (2002) Distributive Justice and Organizational Commitment Revisited: Moderation by Layoff in the Case of Korean Employees. Human Resource Management, 41, 261-270. https://doi.org/10.1002/hrm.10035

[19] Anat, R. and Monica, W. (1999) Symbol in Organization Culture.

[20] Ghafoor, A., Qureshi, T.M., Khan, M.A. and Hijazi, S.T. (2011) Transformational Leadership, Employee Engagement and Performance: Mediating Effect of Psychological Ownership. African Journal of Business Management, 5, 7391. https://doi.org/10.5897/AJBM11.126

[21] Nizam, I. (2016) Effects of Organizational Culture on Employee Performance. International Journal of Accounting \& Business Management, 4, 19-26.

[22] Fernandes, C. and Awamleh, R. (2006) Impact of Organizational Justice in an Expatriate Work Environment. Management Research News, 29, 701-712. https://doi.org/10.1108/01409170610716016

[23] Ambrose, M., Hess, R.L. and Ganesan, S. (2007) The Relationship between Justice and Attitudes: An Examination of Justice Effects on Event and System-Related Attitudes. Organizational Behavior and Human Decision Processes, 103, 21-36.

[24] Neihoff and Moorman (1993) Justice as a Mediator of the Relationship between Methods of Monitoring and Organizational Citizenship Behavior. The Academy of Management Journal, 36, 527-556.

[25] Sieger, P., Bernhard, F. and Frey, U. (2011) Affective Commitment and Job Satisfaction among Non-Family Employees: Investigating the Roles of Justice Perceptions and Psychological Ownership. Journal of Family Business Strategy, 2, 78-89. https://doi.org/10.1016/j.jfbs.2011.03.003

\section{List of Abbreviations}

OJ: Organizational Justice

DJ: Distributive Justice

PJ: Procedural Justice

IJ: Interactional Justice

JB: Job Satisfaction

AV: Average

OJAV: Organizational Justice Average

DJAV: Distributive Justice Average

PJAV: Procedural Justice Average

IJAV: Interactional Justice Average

JBAV: Job satisfaction Average 


\section{Appendix A: Research Questionnaire}

*1) Gender
a) Male
b) Female

*2) Education Level
a) Bachelor Degree
b) Graduate Studies
c) Post Graduate

*3) Age
a) $21-30$
b) $31-40$
c) $41-50$
d) $51-60$

Organizational Justice

DISTRIBUTIVE JUSTICE (refers to how resources are distributed within an organization).

*4) My work schedule is fair.
1) Strongly Disagree
2) Disagree
3) Neutral
4) Agree
5) Strongly Agree

*5) I think my level of pay is fair.
1) Strongly Disagree
2) Disagree
3) Neutral
4) Agree
5) Strongly Agree

*6) I consider my work load to be quite fair.
1) Strongly Disagree
2) Disagree
3) Neutral
4) Agree
5) Strongly Agree

*7) Generally, the rewards I receive here are quite fair.
1) Strongly Disagree
2) Disagree
3) Neutral
4) Agree
5) Strongly Agree

*8) I think my job has several responsibilities.
1) Strongly Disagree
2) Disagree
3) Neutral
4) Agree
5) Strongly Agree

PROCEDURAL JUSTICE (refers to procedures used at your organization to reach decisions).

*9) Job decisions are made by my manager in a biased manner.
1) Strongly Disagree
2) Disagree
3) Neutral
4) Agree
5) Strongly Agree

$\left.{ }^{*} 10\right)$ My manager makes sure that all employee concerns are heard before job decisions are made.
1) Strongly Disagree
2) Disagree
3) Neutral
4) Agree
5) Strongly Agree

*11) To make job decisions, my manager collects accurate and complete information.
1) Strongly Disagree
2) Disagree
3) Neutral
4) Agree
5) Strongly Agree 
*12) My manager clarifies decisions and provides additional information when requested by employees.
1) Strongly Disagree
2) Disagree
3) Neutral
4) Agree
5) Strongly Agree

*13. All job decisions are applied consistently to all affected employees.
1) Strongly Disagree
2) Disagree
3) Neutral
4) Agree
5) Strongly Agree

*14. Employees are allowed to challenge or appeal job decisions made by their managers.
1) Strongly Disagree
2) Disagree
3) Neutral
4) Agree
5) Strongly Agree

INTERACTIONAL JUSTICE (refers to the authority figure that enacts the procedures used at your organization to make decisions).

*15) When decisions are made about my job, my manager treats me with kindness and consideration.
1) Strongly Disagree
2) Disagree
3) Neutral
4) Agree
5) Strongly Agree

*16) When decisions are made about my job, my manager treats me with respect and dignity.
1) Strongly Disagree
2) Disagree
3) Neutral
4) Agree
5) Strongly Agree

*17) When decisions are made about my job, my manager is sensitive to my personal needs.
1) Strongly Disagree
2) Disagree
3) Neutral
4) Agree
5) Strongly Agree

*18) When decisions are made about my job, my manager shows concern for my right as employee.
1) Strongly Disagree
2) Disagree
3) Neutral
4) Agree
5) Strongly Agree

*19) Concerning decisions made about my job, my manager discusses with me the implications of the decisions.
1) Strongly Disagree
2) Disagree
3) Neutral
4) Agree
5) Strongly Agree

*20) My manager offers adequate justification for decisions made about my job.
1) Strongly Disagree
2) Disagree
3) Neutral
4) Agree
5) Strongly Agree

*21) When making decisions about my job, my manager offers explanations that make sense to me. 

1) Strongly Disagree
2) Disagree
3) Neutral
4) Agree
5) Strongly Agree

\section{JOB SATISFACTION}

*23) All in all, I am satisfied with the work of my job.
1) Strongly Disagree
2) Disagree
3) Neutral
4) Agree
5) Strongly Agree

*24) All in all, I am satisfied with my co-workers.
1) Strongly Disagree
2) Disagree
3) Neutral
4) Agree
5) Strongly Agree

*25) All in all, I am satisfied with the supervision.
1) Strongly Disagree
2) Disagree
3) Neutral
4) Agree
5) Strongly Agree

*26) All in all, I am satisfied with my pay.
1) Strongly Disagree
2) Disagree
3) Neutral
4) Agree
5) Strongly Agree

*27) All in all, I am satisfied with the promotional opportunities.
1) Strongly Disagree
2) Disagree
3) Neutral
4) Agree
5) Strongly Agree 